\title{
STATISTICAL PROCESS CONTROL FOR MONITORING EXAMS PRESCRIPTIONS IN MEDICAL COOPERATIVES
}

\author{
Eric Batista FERREIRA ${ }^{1}$ \\ Marcelo Silva de OLIVEIRA ${ }^{2}$ \\ ${ }^{1}$ Adjunct Professor, Exact Sciences Institute, Federal University of Alfenas, Alfenas, Minas Gerais, Brazil. \\ E-mail: eric.ferreira@unifal-mg.edu.br. \\ ${ }^{2}$ Associated Professor, Exact Sciences Department, Federal University of Lavras, Lavras, Minas Gerais, Brazil. \\ E-mail: marcelo.oliveira@dex.ufla.br.
}

\section{Recebido em: 30/05/2014 - Aprovado em: 30/06/2014 - Disponibilizado em: 30/07/2014}

\begin{abstract}
One of the critical control points of quality control for medical cooperatives regards the over prescription of exams by their members. On the other hand, a high number of medical consultations with no exam prescription may indicate a cavalier attitude, leading to a potential disrepute by customers in the medium term. The expectation of exams per doctor is a function of his/her ability of correctly diagnose, medical specialty, ethical and moral principles, among others. This paper suggests the use of Statistical Process Control for monitoring the number of exams prescriptions and illustrates it with a case-study. Such methodology seems to be very useful for managing medical institutions, avoiding unnecessary expenditures but guaranteeing the service quality.
\end{abstract}

Key-words: Statistical Process Control. Medical cooperatives. Control charts. Quality control.

\section{CONTROLE ESTATÍSTICO DE PROCESSO NO MONITORAMENTO DE EXAMES PRESCRITOS EM COOPERTATIVAS MÉDICAS}

\begin{abstract}
Resumo: Um dos grandes problemas relacionados à administração financeira de empresas prestadoras de serviço, tais como as cooperativas médicas, refere-se à solicitação de exames de maneira indiscriminada e sem critérios, devido ao alto custo despendido. Entretanto, não se pode simplesmente restringir a solicitação de exames baseando-se apenas no aspecto financeiro. É preciso considerar outros fatores tais como: a necessidade de cada médico ao determinar o diagnóstico de seus pacientes, as características de cada especialidade, bem como, os princípios éticos e morais. Desta forma, esse trabalho objetivou propor um método alternativo para acompanhamento das despesas relativas à solicitação de exames médicos baseado na teoria de Gestão da Qualidade. Dentro dessa teoria deve-se destacar o Controle Estatístico de Processo (CEP) que, utilizando técnicas gráficas e considerando os fatores mencionados anteriormente, foi ferramenta fundamental na elaboração desse trabalho. Levando-se em consideração todas as restrições inerentes ao contexto das cooperativas médicas, concluiu-se que a utilização do gráfico de médias propiciou bons resultados exploratórios não apenas no aspecto financeiro, mas também na qualidade do atendimento.

Palavras-chave: Controle Estatístico de Processo. Cooperativas médicas. Cartas de controle. Controle de Qualidade.
\end{abstract}




\section{INTRODUCTION}

Medical cooperatives are integrated organizations of doctors aiming to generate job positions for their members and to provide qualified medical assistance in low costs for the local population. The essential difference between the medical cooperatives and other medical organizations is the allegiance to the moral and ethical codes that the doctors submit themselves spontaneously. Those codes say, basically, that the work is the basic element of the economy, while the capital is only an instrument.

One of the critical points of the medical cooperatives financial administration regards the over prescription of exams, since they have high cost. However, one cannot simply restrict the request of such exams based on purely financial arguments, since they are essential for a correct diagnosis. The technical need and the ethical principles must be considered at the same time.

Monitoring exams prescription rates must be carried through by adequate and objective techniques, considering the professional ethics, particular specialty characteristics and the personal ability of each doctor perform the diagnosis. Such techniques however must consider the need of correctly diagnose without unnecessarily extra charging the cooperative. In other words, particularities must be taken into account since they do not charge the cooperative in excess.
After a closer look into such medical cooperatives particularities, it is clear that exams prescription is a fruitful ground for practicing the principles of Total Quality. Saraiva and Andrade (1997) say that the management of the Total Quality does not propose theoretical and rigid concepts, but an effective changing of posture and values. Based on that, the control of medical expends with exams requests requires an effective management procedure allowing a complete, impartial and reliable analysis.

Such a system certainly can have several advantages. Since it is associated with adequate statistical techniques, it can provide information for medical cooperatives to evaluate the behavior of their doctors when consulting diagnosing. In turn, such information can be used as an objective criterion for warning a doctor about the expected behavior or even taken another plausible action.

Therefore, the present work suggests an approach of monitoring exams prescriptions based on the Shewhart control charts, for detecting negligible, heedless and coherent doctors, according to the frequency of exams requested.

Such approach intends to help the financial management of medical cooperatives to act accordingly to the. Conselho Federal de Medicina $\mathrm{N}^{\mathrm{o}} 4.038 / 99$ $\mathrm{PC} / \mathrm{CFM} / \mathrm{N}^{\circ}$ 29/2000: 
"The doctor, in order to better serve the patient, must have autonomy and freedom in his/her profession. If it occurs unnecessary reiterated exams requests and indications of fraudulent procedure, the case must be led to the knowledge of the competent Regional Council, without avoiding dispositions based on internal rules of the harmed instance, respected the constitutional principle of defense. However, harms the Medical Ethics, the limitation of procedures allowed to the doctor (moderator factor), being also ant ethical the punitive dispositions that can be imposed when exceeded the limits considered statistically acceptable (reducing factor)."

Statistical process control is an important statistical area that comprises several tools for controlling, monitoring, acting, correcting and maintaining any productive process. Particularly, the exams request by the doctors of a medical cooperative, along the time, is a process that must be controlled and maintained stable. Among the several tools of the Statistical Process Control, the Shewhart control charts are highlighted (DEMING, 1990), since they are widely used for controlling processes (NOMELINI, 2007).

First, the method allows one to determine a monthly standard measure of the costs concerning the exams request, by specialty. Such monthly standard measured is called Control Limits, and is basically quantiles of a Normal distribution (e.g. 5\% and $95 \%$ ) where the parameters $\mu$ and $\sigma^{2}$ come from the observed data $\left(\bar{x}\right.$ and $\left.s^{2}\right)$. The idea is that observations outside those limits and some non-radon patterns of the observed data indicate a not controlled process. Thus, such limits enable the annalist to detect non- conformities, in the particular case, doctors that request a much smaller of much higher number of exams than the average. Moreover, an historical analysis of previous data enables detecting seasonality, that is, periods of the year when exams request tend to increase or decrease for some reason, and take them into account.

The basic principle for managing public attendance institutions consists of solid information that can assist in the decision making process. In such a way, on the basis of a information system, extends the knowledge in the management aspect, propitiating improvement in the quality of the services and reduction of expenses. Thus, it is essential applying statistical analyses and/or administrative systems of management. Applying statistical techniques can be referred as part of a information system. The use of such techniques as alternative source of information to be aggregate to the systems of medical expenditures can be found in the literature. For instance, Cirillo and Sáfadi (2003) presented an application of time series techniques as alternative for the analyzing hospital expenditures.

Total Quality Control (TQC) is widely related to information systems. According to Werkema (1995), TQC is defined as a management system, whose techniques allow the economic production of goods and services that satisfy the necessities of the consumer. Bouer (1998) describes TQC as a strategic factor in the management scope. The 
whole system of quality is formed by processes. A process represents a combination of elements, methods or procedures having as objective the supply of a good or service (WERKEMA, 1995).

It is appropriate that the whole process is predictable, so it is necessary that it is under statistical control. The scan that finds whether a process is under control or not, in general, is accomplished by graphical techniques. According Slack et al. (1997) the use of graphical procedures is an instrument to check if a particular process is to perform as expected, or alternatively, if it is out of control. If the process shows indications that it is out of control, then decisions should be taken.

Every process has variation, caused by quality characteristics, depending on the existing differences or inconsistencies between results. These sources of variation can be divided into two groups: common and special causes.

Contador et al. (1998), define causa comum como sendo uma fonte de variação que afeta todos os valores individuais de um processo e é resultante de diversas origens, sem que nenhuma tenha predominância sobre a outra. Pode-se resumir a variação comum, como a variação natural de qualquer processo. Ela não pode ser reduzida sem mudanças na concepção do processo.

On the other hand, the special cause is a factor that generates variations that affect the behavior of the unpredictable process. It is also known as sporadic cause, due to their nature. It differs from the common cause by producing totally different results with respect to other values.

A process is said "under control" or "statistically stable" when only common causes are present. However, this is not the natural condition of any process, ie, one should always expect the presence of special causes of variation acting. Through continuous efforts, we must eliminate them until the stabilization process. Since the process is stable and therefore know what to expect if it can be determined whether it is possible to meet customer requirements or specifications by means of other aggregate statistical process control techniques.

\section{METHODOLOGY}

It is important to say that the techniques used in this work can be applied to any area. However, to be in accordance with the proposed objective, we aimed at medical cooperatives.

Two cases can be distinguished in our approach. The first one refers to real data from a (anonymous) Brazilian cooperative. It regards 31 doctors from the same specialty (named XXX), from January 2000. The cost per hour was computed from the exams prescriptions made by these doctors. The software Minitab v. 12.0 was used.

Given such data, we proceeded the construction of the Shewart control chart. It is a "variable chart" for the mean, since the 
response variable is expressed in a continuous scale (WERKEMA, 1995).

The construction of the control chart was given in the following stages:

1) The average exams expense for each doctor was set as the characteristic to be controlled during the monthly period;

2) The information was computed in the order they were obtained;

3) The average costs per doctor $\left(x_{i}\right)$ were computed:

$$
\bar{x}_{i}=\frac{\bar{x}_{i 1}+\bar{x}_{i 2}+\ldots+\bar{x}_{i n}}{n} ; i=1,2, \ldots, n
$$

4) The global average was computed, that is, the average of the specialty:

$$
\overline{\bar{x}}=\frac{\bar{x}_{1}+\bar{x}_{2}+\ldots+\bar{x}_{n}}{n} ; i=1,2, \ldots, n
$$

5) The control limits were computed: Lower Control Limite (LCL), Central Line (CL) and the Upper Control Limit (UCL):

$$
\begin{gathered}
L C L=\overline{\bar{x}}-3 s \\
C L=\overline{\bar{x}} \\
U C L=\overline{\bar{x}}+3 s
\end{gathered}
$$

were $\mathrm{s}$ represents the sample standard deviation.

6) Both limits and average points were plotted, representing the average expense for each doctor of the fixed specialty.

After the construction of the average chart, it was interpreted from both statistical and economic/administrative point of view.

Repeating this process monthly, during a defined period of time, a historical series can be generated, whose expenditure tracking would identify trends or even establish a historical average for each specialty.

For this reason, a simulation study was carried out, representing the second case of this approach. Nine doctors were simulated (3 per specialty). In each specialty, the three doctors were, respectively, a heedless, a coherent and a negligent. Thirty months were simulated, whose contained twenty four observations per month. The linear model used for such simulation was:

$$
\mathrm{y}_{\mathrm{ijk}}=\mu+\alpha_{\mathrm{i}}+\beta_{\mathrm{j}}+\mathrm{e}_{\mathrm{ijk}}
$$

where $y_{i j k}$ is the $k$ th observation of the $j$ th doctor from the $i$ th specialty; $\mu$ is a common constant; $\alpha_{\mathrm{i}}$ is the effect of the ith specialty; $\beta_{\mathrm{j}}$ is the effect of the jth doctor; $e_{i j k}$ is the random error associated with the observation $y_{i j k}$. The common constant $\mu$ was set to 5,000 monetary unities (m.o.), without loss of generality. Specialty effects were set to 500, 1,500 and 2,500; and doctor effects were set to $0,0.5$ and -0.5 times the specialty effect, respectively for coherent, negligent and heedless. Random errors were considered normal with null mean and fixed variance.

\section{RESULTS AND DISCUSSION}

Basically, the described methodology in this work consists of adding referring information to the control of medical expenditures for the taking of decisions. With this purpose the averages chart, presented for figure 1 , revealed inside adequate of the considered objective. However, its 
interpretation must be carefully made, points of view (Figure 1). regarding both economic and statistician

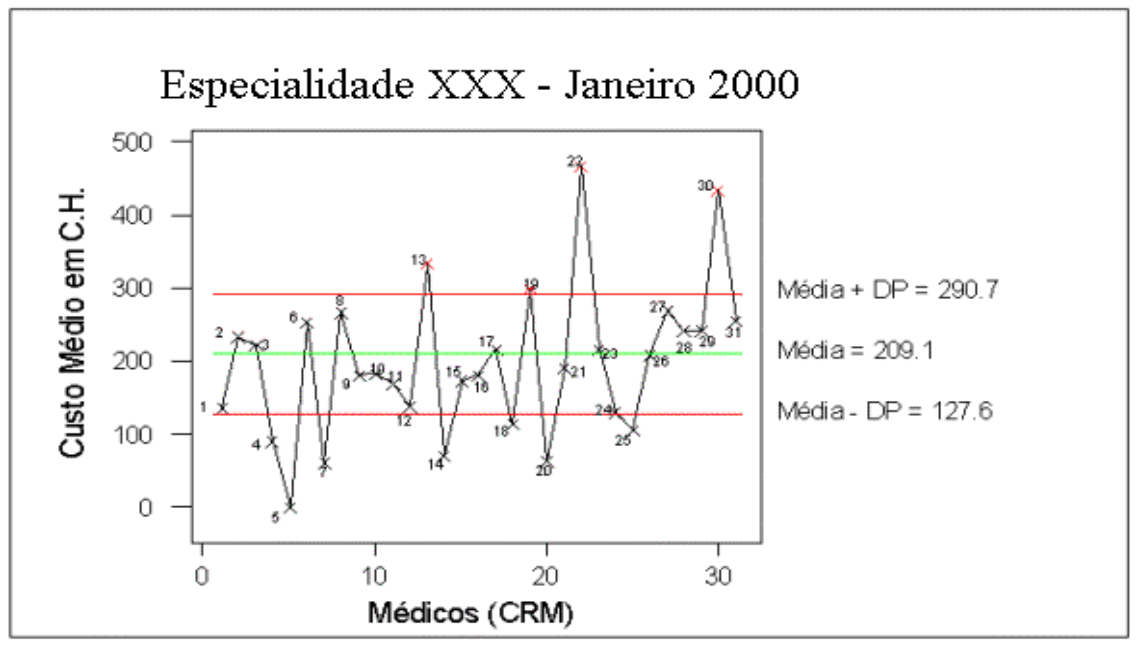

Figure 1 - Averages control chart for 31 doctors from a Brazilian medical cooperative.

In accordance with the results presented by means of Figure 1, it was become fulfilled interpretation in relation to the economic and statistical aspects.

The statistical meaning is obtained in a very simple way. One just has to inspection points positioned outside the control limits. In Figure 1, the UCL was represented by the expression overall mean + standard error; LCL was represented by the expression overall mean - standard error, i.e., the overall mean plus or minus three standard deviations from the average, respectively. Outside this range formed by two limits, the point is considered out of control and needs attention and corrective action by the responsible administrator(s).

Observing the points below the LCL, one might suspect that those doctors represented by such points are having low demand. It is desired that a physician submits an average of less than the minimum expected (LCL) required exams. This result may indicate low quality services, such as doctors that are not asking for the minimum number of exams for an accurate diagnosis. It is evident that other causes should be highlighted to obtain more robust conclusions. That's why control chart is merely an exploratory tool and should be used joined with other techniques.

Those points positioned above the UCL represent physicians who requested a number of exams beyond that expected to generate a diagnosis. Therefore, the cause must be quickly investigated, because the excessive testing represents a strong economic impact on the cooperative system.

The economic interpretation should be taken with caution, because the trend is, at 
first glance, verify that the points above the upper control limit represent a truly unnecessary expense in exams prescription. However, it should be noted that this analysis should not be referenced simply the economic interest of the cooperative. That is, control of medical expenses should be done in an absolutely ethical manner. So the fact of noncompliance of some statistic, ie, a doctor show the number of tests requested outside the control limits, should not necessarily result in corrective and / or punitive action . Other factors such as assessing the need for requesting tests for the diagnosis in question and seasonality in care, should be considered. For instance, exams related to the pulmonology specialty are more required in winter than in summer.

Finally, this analysis is recommended only as a generator of exploratory results. It features the use of these data as an alternative contribution to information concerning medical expenses.

It is important to say that the identification of a particular doctor outside the control limits do not have the immediate punishment of the professional goal, but the investigation of the causes of noncompliance. That is, this statistical tool lets you create a culture of accountability within the medical profession, which is perfectly healthy and ethical.

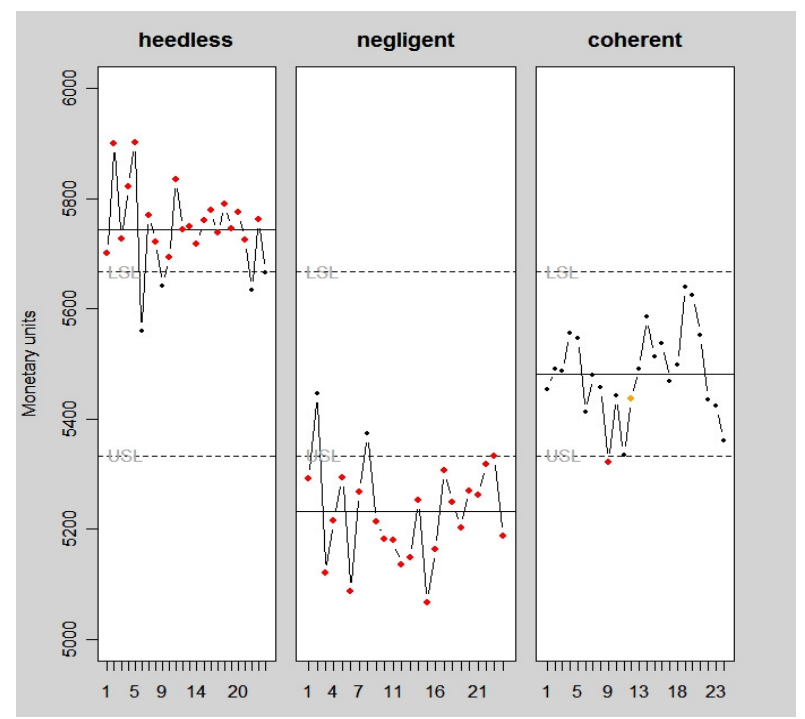

(A)

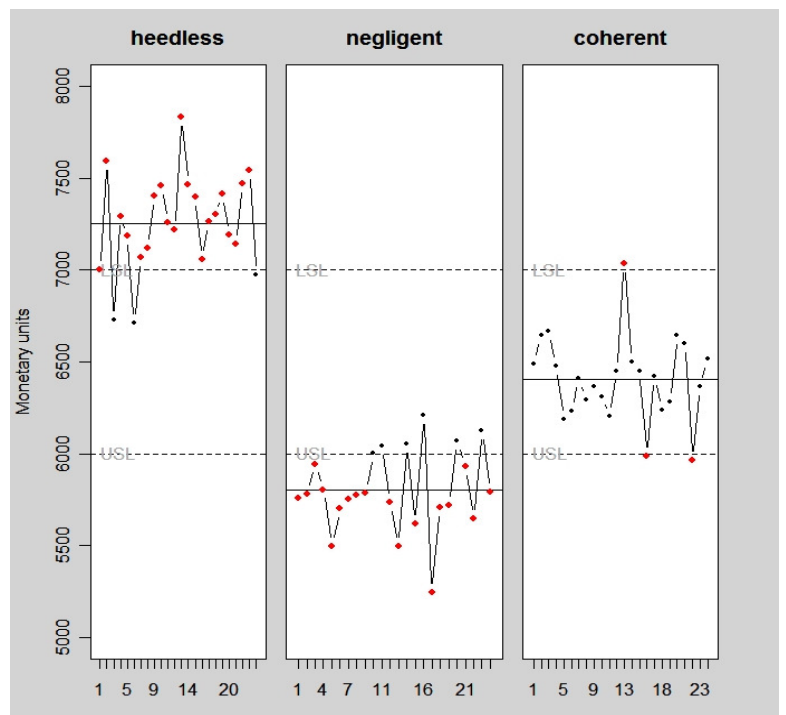

(B)

Figure 2 - Simulation results for heedless, negligent an coherent doctors for specialty A and B.

Regarding the simulation study, results can be seen in Figure 2. Under a theoretical data generator mechanism, according to a linear model, it is easy to accept that heedless and negligent doctors would be promptly identified in a real situation, using this method. In Figure 2, specialties A and B are displayed. Specialty $\mathrm{C}$ is omitted due to its similar behavior. 


\section{CONCLUSIONS}

a) The control chart is adequate as an exploratory tool to control medical costs, and its proper use in addiction to other information systems.

b) Future works should explore real time series of cooperative costs, monitoring monthly the variations, providing results that can contribute to decision making, avoiding harming the doctor, the patient or the cooperative.

\section{REFERENCES}

BOUER, G. Gestão de Operações: Capítulo 14 - Qualidade: Conceitos e Abordagens, Editora Edgard Blücher Ltda, Fundação Vanzolini, 2a Edição, São Paulo, 1998.

CONTADOR, J.C. Gestão de Operações, Editora Edgard Blücher Ltda, Fundação Vanzolini, 2a Edição, São Paulo, 1998.

CIRILLO, M.A.; SÁFADI,T. Modelos de séries temporais aplicados a índices de preços hospitalares do Hospital da Universidade Federal de Santa Catarina. Organizações Rurais e Agroindustriais, v.5 n.1, Lavras MG, 2003.

DEMING, W.E. Qualidade: a revolução da administração. Rio de Janeiro: Marques Saraiva, 1990. 01-367p. uma manufatura de autopeças: Um enfoque Seis Sigma: Universidade Federal de Lavras. 2007. 182p. (Master Dissertation).

Parecer do Conselho Federal de Medicina sobre a Medicina sobre a Meta Referencial (Fator Redutor ou Mediador) - CFM N ${ }^{\circ}$ 4.038/99PC/CFM/No 29/2000, Disponível em $<\underline{\text { http://noticias.cardiol.br/ }}$ http://noticias.cardiol.br/>, Acesso: 25/07/2003.

SARAIVA, J.M.M.; ANDRADE J.G.

Qualidade Total, Editora FAEPE Fundação de Apoio ao Ensino, UFLA, Lavras, MG, 1997.

SLACK, N.; CHAMBERS, S.T.; HARLAND, C.; HARRISON, A. JOHNSTON, R.; Administração da Produção. Warmick Business School, University of Warnick, São Paulo : Editora Atlas S.A. 1997.

\section{WERKEMA, M.C.C. Ferramentas}

Estatísticas Básicas para o Gerenciamento

de Processos, Série: Ferramentas da Qualidade - TQC Gestão pela Qualidade Total, v.2, Belo Horizonte, MG, UFMG, 1995.

NOMELINI, Q. S. S. Racionalização do

Controle Estatístico de Processo (CEP) em 